\title{
Implementation of International Master's Programmes in Engineering Education in Germany
}

\author{
Strenger, Natascha ${ }^{a}$ and Frerich, Sulamith ${ }^{\mathrm{a}}$ \\ ${ }^{\mathrm{a}}$ Department of Mechanical Engineering, Ruhr Universität Bochum, Germany.
}

\begin{abstract}
This paper introduces the framework conditions of the internationalization process of the higher education system in Germany and gives an overview of the implementation of international Master's programmes in engineering education and the characteristics of student migrants in this field of studies. Developments on the macro-level clearly indicate political interest to attract more international students for German universities and the technical disciplines in Germany are already very successful in this endeavour. With a special focus on higher education reforms in engineering, this paper is based on an investigation directed at the meso-level, the motivations and strategies at the level of university and faculties for establishing such international study programmes. The results of a qualitative study will be presented that was conducted at the engineering faculties of the Ruhr-Universität in Bochum between December 2014 and August 2015. With the overall aim of investigating in how far the decisions made on university and faculty levels are related to the general political endeavors to attract international talent, the different stakeholders' interests and implementation strategies such as language policy were considered.
\end{abstract}

Keywords: Internationalization; Higher Education Reforms; Student Migration; International Master Degree Courses. 


\section{Introduction}

Facing a predicted shortage of highly qualified workers due to demographic change and the loss of human capital through emigration (SVR 2011), Germany and fellow industrialized nations have long since recognized the potential of international students who might be recruited as highly qualified talent in the areas of science and technology (Chaloff \& Lemaitre 2009; Bhandari et al. 2011).

In Germany, the structural changes that took place in its higher education system during the last 20 years nowadays appear to work rather effectively in attracting such international talent. After the General Agreement on Trade in Services (GATS) in 1995 had liberalized the sector of tertiary education along with the global exchange of services in general, the amendment to the Framework Act for Higher Education in 1998 finally opened the possibility for fundamental changes to the system of study courses and degrees at German universities. With the overall goal of attracting more international students, those now began to gradually implement the two-stage model of Bachelor's and Master's degrees, thus replacing the one-stage system with Diploma and Magister degrees (Schnitzer 1999).

The substantial reformation process of the German higher education system allowed for the implementation of international degree courses. While in the old system recognition of study periods and degrees from foreign universities had been difficult, the overall goal was now to attract more highly-qualified, international talent by facilitating the access to German study programmes. To achieve this, new degree courses were designed according to their clientele's needs, especially with regard to language requirements and organizational support (KMK 1997). Supported by the German government and the German Academic Exchange Service (DAAD) with special funding programmes, German higher education institutions were particularly eager to implement such internationallyoriented study courses on the Master's level.

In this process of implementing new degree courses at German universities, the engineering disciplines were among the first to develop internationally-oriented offers. As student numbers in this field were still comparatively low, the attraction of international talent was seen as a welcome opportunity (Rotter 2005). About 15 years in the process of implementing the two-phase study model and international degree programs in the German higher education system, the database of the DAAD today lists no less than 800 international Master degree courses and 140 international Bachelor's programmes (DAAD 2015). Defining the subject criterion "engineering", this database reveals 245 international Master degree courses.

Germany belongs to the countries that draw the highest amount of all student migration (exchange and degree mobility) in engineering education. (Macready \& Tucker 2011). Of all disciplines chosen by international students in Germany, engineering belongs to the 
most popular ones with a percentage of $25 \%$ (Apolinarsky et al. 2013). In comparison, only $19.8 \%$ of all German students are enrolled in technical study courses. With regard to the distribution among study phases, the largest share of international students who study engineering in Germany is actually enrolled in Master degree courses. In contrast to this, foreign students of the humanities have the largest share in bachelor's degree courses and students of natural sciences in the $\mathrm{PhD}$ phase (ibid.).

There are several noteworthy characteristics of student migrants in German engineering disciplines, one of them being their national background: By far the largest shares of international engineering students in Germany (with $40 \%$ each) are of East-Asian or Asian nationality (ibid.). In general, a high amount of foreign students in the technical subjects in Germany is from countries with low to upper middle per capita income and only $17 \%$ from high-income countries. The largest share of international students from countries with high per capita income $(36 \%)$ is enrolled in the humanities, especially languages and cultural studies, in Germany. The comparison of technical and cultural disciplines also indicates a gender-specific distribution: While the cultural and philological studies are clearly dominated by female students (36\% from developing countries, $44 \%$ from industrialized countries), the engineering disciplines are preferred by male international students in Germany (36\% of all foreign students from developing countries, $27 \%$ from industrialized nations) (Schnitzer 1999).

The following sections of this paper describe the results of a case study that aimed at investigating the meso-level of academic migration in engineering: The level of engineering faculties and decision-makers at universities who decide on ways to implement new study programs and who find themselves in between political decisions on the German higher education system (macro-level) and the student migrants themselves (micro-level). This paper presents work in progress, with the outlook of investigating the student's perspective in the near future.

\section{Case Study: International Master Degree Courses in Engineering at the Ruhr Universität Bochum}

\subsection{Object of Investigation and Research Design}

The Ruhr Universität Bochum (RUB) is located in the area of the Ruhr in Germany and home to 5,600 employees and more than 41,000 students at 20 faculties. Over 7,000 students study at its three engineering faculties. The RUB was one of the first universities in Germany to implement the two-stage model of Bachelor's and Master's degrees. The international study course Computational Engineering at RUB for example was one of the first to be funded by the programme "internationally oriented courses" by the German Academic Exchange Service, the DAAD (Rotter 2005, S. 172). Today, there are seven 
international Master's programmes in Engineering and Natural Sciences at the Ruhr Universität Bochum and an extension of this offer is planned as part of the university's internationalization strategy. Some of the international degree courses received additional funding by a rectorate programme called "Master 2.0" in 2011, designed to support the implementation of study programmes that are interdisciplinary and strongly researchoriented, as well as international. This investigation was directed at three international Master degree courses in the RUB's engineering disciplines: Computational Engineering, Lasers and Photonics, as well as Materials Science and Simulations.

Based on a thorough study of secondary literature on internationalization of the German higher education system and specifics of academic migration in engineering education, guidelines for a qualitative study with semi-structured interviews were developed. The interviews (a total of 6, with 1-2 persons and about 90 minutes each) were conducted between December 2014 and August 2015 with study coordinators and persons in charge of these three international Master degree courses at RUB, as well as the person responsible for international Master's programmes at the university. In order to retrace the decisions made on these institutional levels regarding the programmes' implementation, the key questions were directed at the overall goals driving the different stakeholders as well as the programmes' language policy. Furthermore, interview partners were asked for an assessment of the actual application situation and the composition of student body.

\subsection{Stakeholders' Motivations and Implementation Processes}

The three international Master degree courses in the focus of this research are anchored in the three engineering faculties of the Ruhr-Universität: While Computational Engineering (Comp. Eng.) is located at the Faculty of Civil and Environmental Engineering, the organization of Lasers and Photonics (LAP) is a cooperative project of the Faculty of Electrical Engineering and Information Technology and the Faculty of Mechanical Engineering (supported in teaching and projects also by other faculties such as Physics, Astronomy, Chemistry and Biochemistry). Materials Science and Simulation (MSS) belongs to the Interdisciplinary Centre for Advanced Materials Simulation (ICAMS), which was established as a research centre in public-private partnership between the Federal State of North Rhine-Westphalia and industry partners. The implementation of an international Master degree course was included in the framework agreement of this institute. While Comp. Eng. already started off in 2000 and was partly funded by the DAAD as mentioned above, both LAP and MSS received their first students in 2011.

On the level of the university rectorate, international Master degree courses were (and still are) called for as part of the overall internationalization strategy and are partly supported financially (as was the case for LAP and MSS through the funding of "Master 2.0"), mainly with funds for organizational support. Yet, the interviews with rectorate and faculty 
representatives showed that the main initiative for a programme's implementation had to come from the respective institutes, engineering faculties and/or chair(s) involved on the content-related side. The main reason for implementing these international degree courses on the engineering faculties' (and partly employers') side was the acquisition of suitably qualified doctoral candidates. According to them, it is getting increasingly difficult to recruit enough candidates from German engineering (or natural science) students at the bottleneck of certain highly-specified, interdisciplinary research areas.

\subsection{Language Requirements}

Internationality is defined similarly by these three programmes: They are open to international as well as German students and their course offer is taught entirely in English. This language prioritization presents a sharp contrast to the regular degree courses at the RUB engineering faculties, whose course offer is (still) mostly taught in German. As the study programmes are taught in English, foreign applicants do not need to provide any proof of German language skills for their application. They need however to certify a sufficient knowledge of the English language via test results from TOEFL (e.g. with a minimum score of 550 in the paper-based test), IELTS or similar. From the viewpoint of the chairs and faculties responsible for the implementation of the Master degree courses, it is essential to offer international students the possibility to study completely in English in order to receive a sufficient amount of qualified applications to select from. According to their estimation, application numbers (which currently amount to several hundreds) would be significantly lower if the programmes were offered in German or German/English.

However, the interviews also showed that the coordinators of the Master's programmes put a strong emphasis on the importance of German language skills for the German labour market and regularly advice international students to take German classes during their studies. They are aware that while good English skills suffice to do $\mathrm{PhD}$ research at their chairs and faculties, employers (especially of small and medium-sized companies) in Germany still require at least a solid basic knowledge of German. Moreover, as the coordinators of Computational Engineering put forward, they are starting to demand German skills also from students applying for research positions, as these language skills are still important for teaching positions at the Engineering Faculties whose regular curriculum is mostly in German.

\subsection{Composition of Student Body and Challenges to be Faced}

The composition of student body is similar in all three programmes: By far the largest share of students is male and from Asia and East-Asia. Top among the list of countries of origin are India, Iran, Pakistan and China, followed by Russia and Eastern European countries. A smaller number of students come from North America or Western Europe to study in 
Germany. Although all Master degree courses are open to international and German students alike, there are only a few German students enrolled in all three programmes.

Table 1. Distribution of Nationalities among Students. (Total number of students in all three Master degree courses, winter term 2013/14).

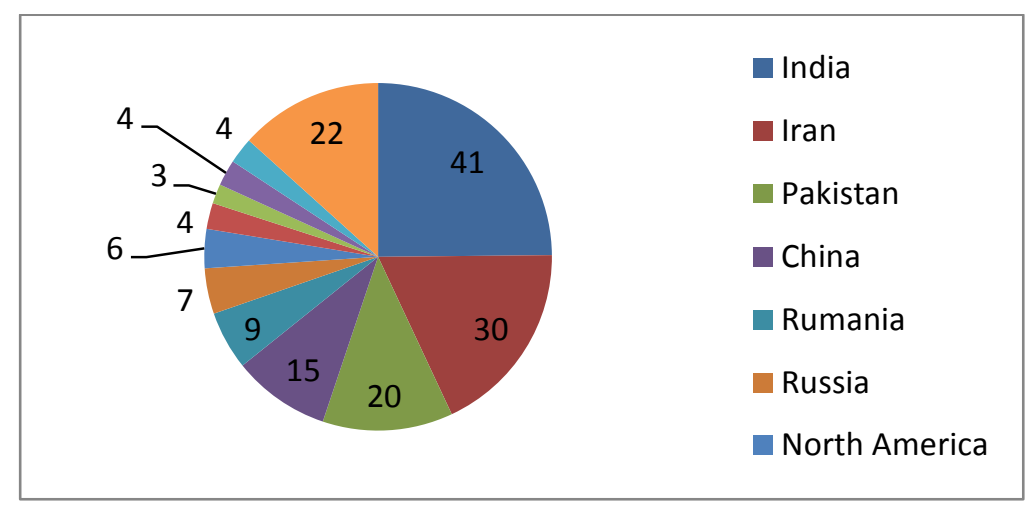

Source: Own depiction, Data Warehouse Ruhr-Universität Bochum (2014)

Regarding the distribution among nationalities, all three programmes would wish for more diversity and try to promote it through their selection processes. However, the total application numbers from Indian, Iranian or Chinese students are so high (with several hundred Indian applicants each year for Comp. Eng. for example), that even a weighting in favor of underrepresented countries cannot provide an even distribution.

A major challenge the study coordinators are facing during the application process (apart from the high numbers of application documents that have to be dealt with) is evaluating the qualifications international students earned at their home universities. For although Bachelor and Master are globally known and accepted degrees by now, highly interdisciplinary requirements of these Master's programmes make it hard to judge whether first study phases at a foreign university provides the applicant with a sufficient basic knowledge in the different fields. Fortunately, this evaluation becomes easier with increasing numbers of applicants who come from the same home institutions over the years, often after having learnt about the German study offers from professors or fellow students at home.

Once selected, the study coordinators assess their students a generally high motivation and eagerness for their studies. On the other hand, they note that only a small number of students come to Germany with prior knowledge of the German language. Thus, while most of them intend to learn German when in Germany, this endeavor turns out to be more difficult for most of them than they might have expected. The combined situations that only few fellow students in these international programmes are German and that there are 
usually large groups of one nationality lead to a lack in opportunities of German-speaking interaction. Moreover, the work load of studies (which most international students try to fulfil within the regular time because they cannot afford to prolong their studies in Germany) does not allow for many extracurricular courses and activities. All three programmes are therefore trying to encourage student's initiatives such as language tandems or free time activities that bring them closer together not only as a group within their study programme (which already seems to work very well), but also with German engineering students. However, the organization and support of such international Master's is already a very time and cost intensive project for the chairs and faculties, so capacities are rather limited.

\section{Conclusions and Potential for Further Research}

The three international Master's programmes in the engineering sciences at the Ruhr Universität Bochum belong to the large share of international degree courses in Germany that are open to international as well as German students, while being taught entirely in English. The composition of their student body corresponds to the general specifics of international engineering students in Germany. With regard to the stakeholders involved in the implementation of such international study programmes and their motivations, it can be said that while university rectorate and even external employers are in some cases involved in planning processes and funding, the organizational responsibility lies mostly with decentralized organizational units such as the ICAMS institute and the three engineering faculties. Decisions to offer the programmes in English only were in all cases made in order to attract high numbers of qualified international students, partly to win suitable doctoral candidates for the research of the chairs and institutes involved. However, learning German is being recognized as a central asset by programme coordinators and they try to promote this among students. A rather homogeneous distribution of national backgrounds and lacking interaction with German-speaking students present the largest challenges for these international Master degree courses, together with difficulties in the assessment of qualifications from foreign universities in the application process.

Complementary to this investigation on the meso level of internationalization processes in higher engineering education, the motivations and decisions of international students who come to Germany to study in international Master's programmes might be the object of future research. It would be interesting to analyze whether student's intentions to work in the host country after graduating from their studies affect their selection of destination country and whether experiences (such as language acquisition) during their studies make them change their plans. Considering the student's viewpoint on international Master degree courses in this way would help to clarify whether - and how - stakeholder's goals of attracting highly qualified talent can be achieved through the implementation of such programmes. 


\section{References}

Apolinarski, B. Poskowsky, J., Kandulla M. \& Naumann, H. (2013). Ausländische Studierende in Deutschland 2012. Ergebnisse der 20. Sozialerhebung des Deutschen Studentenwerks durchgeführt vom Deutschen Zentrum für Hochschul- und Wissenschaftsforschung (DZHW). Berlin.

Bhandari, R. Belyavina, R. \& Gutierrez, R. (2011). Student mobility and the internationalization of higher education: National policies and strategies from six world regions. Institute of International Education, New York.

Chaloff, J. \& Lemaitre, G. (2009). Managing highly-skilled labour migration: A comparative analysis of migration policies and challenges in OECD countries. OECD Social, Employment and Migration Working Papers (79).

Data Warehouse System / Controlling at Ruhr Universität Bochum: http://dwh.uv.ruhr-unibochum.de/aufgaben/planung-controlling-berichtswesen/statistik/

Expert Council of German Foundations for Integration and Migration (SVR) (2011). Jahresgutachten 2011 mit Migrationsbarometer.Available online: http://oezoguz.de/wpcontent/uploads/2011/04/Integrationsbarometer_2011_des_SVR.pdf

German Academic Exchange Service (DAAD) (2015). Online database of international study programmes in Germany:

https://www.daad.de/deutschland/studienangebote/international-programs/en/

Standing Conference of the Ministers of Education and Cultural Affairs of the Länder in the Federal Republic of Germany (KMK) (1997). Stärkung der internationalen Wettbewerbsfähigkeit des Studienstandortes Deutschland. Available online: http://www.kmk.org/fileadmin/veroeffentlichungen_beschluesse/1997/1997_10_24Staerkung-Wettbewerb-Studienstandort-Deutschl.pdf

Macready, C. \& Tucker, C. (2011). Who goes where and why? An Overview and Analysis of Global Educational Mobility. New York.

Rotter, C. (2005). Internationalisierung von Studiengängen. Typen, Praxis, Empirische Befunde. Available online: http://www-brs.ub.ruhruni-bochum.de/netahtml/HSS/Diss/RotterCarolin/

Schnitzer, K. (1999). Wirtschaftliche und soziale Lage der ausländischen Studierenden in Deutschland. Federal Ministry of Migration and Refugees (BMBF), Higher Education Information System (HIS), German Student Union (DSW), Bonn. 